\title{
Antibacterial Activity of Vernonia amygdalina Leaf Extracts against Multidrug Resistant Bacterial Isolates
}

\section{${ }^{* 1}$ EVBUOMWAN, L; ${ }^{2}$ CHUKWUKA, EP; ${ }^{1}$ OBAZENU, EI; ${ }^{1}$ ILEVBARE, L}

\author{
${ }^{1 *}$ Department of Microbiology, Faculty of Life Sciences, University of Benin, Benin City, Nigeria. \\ ${ }^{2}$ Laboratory Department, Maternity and Children Hospital, Al Mubaraz, Al Ahsa, Saudi Arabia \\ "Corresponding author Email: evbuomwanlucky1@gmail.com
}

\begin{abstract}
This study was undertaken to investigate the phytochemical and antibacterial activities of Vernonia amygdalina leaf extract against clinical isolates obtained from the University of Benin Teaching Hospital, using agar well diffusion method. Phytochemicals present in Vernonia amygdalin included flavonoids, cardiac glycosides, reducing sugar, terpenoids and saponins. Ethanolic extract acted against with inhibition zones ranging from $7.0 \pm 0.0 \mathrm{~mm}$ at $25 \mathrm{mg} / \mathrm{ml}$ to $14.5 \pm 2.5 \mathrm{~mm}$ at $200 \mathrm{mg} / \mathrm{ml}$ against E. coli; $6.5 \pm 0.5 \mathrm{~mm}$ at $100 \mathrm{mg} / \mathrm{ml}$ to $9.0 \pm 2.0 \mathrm{~mm}$ at $200 \mathrm{mg} / \mathrm{ml}$ against $S$. aureus; $11.0 \pm 1.0 \mathrm{~mm}$ at $50 \mathrm{mg} / \mathrm{ml}$ to $16.5 \pm 5.0 \mathrm{~mm}$ at $200 \mathrm{mg} / \mathrm{ml} ; 7.5 \pm 1.5 \mathrm{~mm}$ at $25 \mathrm{mg} / \mathrm{ml}$ to $11.5 \pm 0.5 \mathrm{~mm}$ at $200 \mathrm{mg} / \mathrm{ml}$. Inhibition zones in aqueous extract ranged from $8.0 \pm 2.0 \mathrm{~mm}$ at $25 \mathrm{mg} / \mathrm{ml}$ to $12.5 \pm 1.5$ at $200 \mathrm{mg} / \mathrm{ml}$ against $P$. aeruginosa; $9.0 \pm 1.0 \mathrm{~mm}$ at $50 \mathrm{mg} / \mathrm{ml}$ to $15.0 \pm 1.5 \mathrm{~mm}$ at $200 \mathrm{mg} / \mathrm{ml}$ against $S$ aureus. The minimum inhibitory concentration of ethanolic extract ranged from $25 \mathrm{mg} / \mathrm{ml}$ in $S$. aureus, P. aeruginosa, B. subtilis and $K$. pneumoniae to $50 \mathrm{mg} / \mathrm{ml}$ in E. coli. Minimum bactericidal concentration of the ethanol extract was $50 \mathrm{mg} / \mathrm{ml}$ in $P$. aeruginosa and $K$. pneumonia and $100 \mathrm{mg} / \mathrm{ml}$ for $E$. coli, S. aureus and B. subtilis. MBC of $200 \mathrm{mg} / \mathrm{ml}$ was observed for B. subtilis, S. aureus and P. aeruginosa in the aqueous fraction of the plant. The most antibiotic resistant bacterial strain was $S$. aureus $(80 \%)$ while the least resistant was $P$. aeruginosa $(10 \%)$. The most resistant bacterial strain was S. aureus $(80 \%)$ while the least resistant was $P$. aeruginosa $(10 \%)$. The most effective antibiotics were perfloxacin, ciprofloxacin, septrin and choramphenicol. Vernonia amygdalina extract was found to be more potent than conventional antibiotics.
\end{abstract}

\section{DOI: https://dx.doi.org/10.4314/jasem.v22i1.4}

Copyright: Copyright (c) 2017 Evbuomwan et al. This is an open access article distributed under the Creative Commons Attribution License (CCL), which permits unrestricted use, distribution, and reproduction in any medium, provided the original work is properly cited

Dates: Received 11 November 2017; received in revised form 14 December 2017; accepted 30 December 2017

Keywords: Antimicrobial, Phytochemical, Antibiotics, Susceptibility, Resistance

The World Health Organization (WHO) estimates that approximately $80 \%$ of the world's inhabitants rely on traditional or herbal medicines for their primary health care and plants have long formed the basis of sophisticated traditional medicine systems and purportedly provide excellent leads for new drug developments (Sofowora, 1993; Pravi, 2006; Akinjogunla et al., 2009). Herbal medicine is the oldest form of healthcare known to mankind and over $50 \%$ of all modern clinical drugs are of natural products origin and natural products play important roles in drug development in the pharmaceutical industry (Preethi et al., 2010). The rediscovery of the connection between plants and health is responsible for the launching of a new generation of multicomponent botanical drugs, dietary supplements and plant produced recombinant proteins (Akinjogunla et al., 2011). However, the increasing problems of multidrug resistant (MDR) bacteria is of great concern to both the clinicians and pharmaceutical industries and this has made it significant to search for newer drugs that are highly effective, affordable, acceptable and available (Martino et al., 2002; Akinjogunla et al., 2011).
Vernonia amygdalina, a species in thefamily Asteraceae, is a tropical shrub with height of $1-3 \mathrm{~mm}$, petiole leaf of about $6 \mathrm{~mm}$ in diameter (Ibrahim et al., 2009). Vernonia amygdalina commonly called bitter leaf in English, "oriwo" in Edo, "ewuro" in Yoruba, "shikawa" in Hausa, and "olubu" in Igbo (Oboh and Masodje, 2009). The leaves are consumed as vegetable and condiments, after macerating andwashing thoroughly to remove the bitterness. The bitter $V$. amygdalinais due to the presence of alkaloids, saponins, tannins and glycosides. Antihelmitic, antimalarial, antitumourigenic, hypoglycemic and hypolipidaemic properties of Vernonia amygdalina have been reported (Izevbigie et al., 2004). Medicinal plants are known to contain substances which could be used for treatment purposes or used to produce drugs. Many of such plants known to be used primitively to alleviate symptoms of illnesses have been screened to have medicinal importance, some of which include: Azadirachta indica (Dogonyaro), $V$. amygdalina (Bitter leaf), Allium sativum (Garlic), O. gratissimum (Scent leaf), and Zingiber officinale (Ginger). These plants have been reportedly used in the treatment of 
ailments such as stomach disorder, fever symptoms and cough traditionally (Yedjou et al., 2008). Medicinal plants play vital roles in the health of individuals and the communities. The medicinal value of some plants lies in some chemical substances that produce definite physiological actions in the human body. Examples of these most important bioactive constituents are alkaloids, tannis, flavonoids and phenolic compound. The leaves of Vernonia amygdalina are green with a characteristic odour and bitter taste.

Vernonia amygdalina is a valuable medicinal plant that is widespread in West Africa, it is known as bitter leaf due to its characteristic bitter taste and flavour, and can be used as an active anticancer, antibacterial, antimalarial and antiparastic agent. This plant contains complex active components that are useful pharmacologically. In ethno medicine, the roots and the leaves are used to treat fever, hiccups, kidney problems and stomach discomfort. Many West African countries such as Cameroon, Ghana and Nigeria use the stem and root as chewing sticks (Koshy et al., 2009). It is also documented that $V$. amygdalina has been used traditionally in blood clothing and has elicited a substantial reduction in the level of glucose in the blood at post-prandial time point. In this study, the antibacterial and phytochemical activity of $V$. amygdalina was carried out.

\section{MATERIALS AND METHODS}

Plant Materials: Vernonia amygdalina leaves purchased from a local market. The leaves were air dried, ground using a blender. The powdered leaf was kept in bottle container until required.

Preparation of Crude Extracts: The method of Idris et al. (2009) was used. Fifty gram $(50 \mathrm{~g})$ of the grinded plant material was soaked in $250 \mathrm{ml}$ each of distilled water and ethanol for 24 hours. The extract was filtered through a sieve to remove debris. The filtrate was then filtered through filter paper. The final filtrate was evaporated in a water bath at $40^{\circ} \mathrm{C}$ to get the crude extract. The crude aqueous and ethanol extract was stored at $4^{\circ} \mathrm{C}$ until required. This was used for phytochemical and antimicrobial analysis.

Preparation of Concentration of Plant Extract: One gram $(1 \mathrm{~g})$ each of both ethanol and aqueous extract was added to $5 \mathrm{ml}$ of ethanol and distilled water respectively to give a concentration of $200 \mathrm{mg} / \mathrm{ml}$. Other concentrations of $100,50,25$ and $12.5 \mathrm{mg} / \mathrm{ml}$ were prepared by double dilution method as described by Iqbal and Arina (2001).
Phytochemical Screening of Extract: Phytochemical parameters of glycosides, steroids, flavonoids, tannins, alkaloids, proteins, saponins, quinines and sugars of the Vernonia amygdalina were determined by standard methods.

Test for Glycosides: A $25 \mathrm{ml}$ of dilute $\mathrm{H}_{2} \mathrm{SO}_{4}$ was added to $5 \mathrm{ml}$ of plant extract in a $100 \mathrm{ml}$ flask. It was boiled (15 min), cooled and neutralized with $10 \%$ $\mathrm{NaOH}$. The fehling solution A and $\mathrm{B}(5 \mathrm{ml})$ was added to the neutralized solution and a brick red precipitate of reducing sugars indicates the presence of glycosides.

Test for steroids: One gram of the test substance (plant extracts) was dissolved in a few drops of acetic acid. It was gently warmed and cooled under the tap water and a drop of concentrated sulphuric acid was added along the sides of the test tube. Appearance of green colour indicates the presence of Steroids.

Test for tannins: The substance (extracts) was mixed with basic lead acetate solution. Absence of formation of white precipitate indicated the absence of Tannins.

Test for alkaloids: Test substance (plant extracts powder) was shaken with few drops of $2 \mathrm{~N}$ HCL. An aqueous layer formed which was decanted and one or two drops of Mayer's reagent added. Formation of white turbidity or precipitate indicates the presence of alkaloids

Test for flavonoids: Shinado's test: To the substance (extracts) in alcohol, few magnesium turnings and few drops of concentrated hydrochloric acid were added and boiled for five minutes. Red coloration shows the presence of Flavonoids.

Test for saponins: The substance (extracts) shaken with water, foamy lather formation indicates the presence of saponins.

Test for quinones: To the test substance, sodium hydroxide was added. Blue green or red color indicates the presence of Quinone.

Test Microorganisms: Two Gram positive (Staphylococcus aureus and Bacillus subtilis) and three Gram negative (Escherichia coli, Pseudomonas aeruginosa and Klebsiella pneumoniae) were used in this study. The microorganisms were obtained from the MicrobiologyLaboratory stocks in University of Benin Teaching hospital. The bacterial strains were grown in nutrient agar (NA) plates at $37^{\circ} \mathrm{C}$.

Antibiotics Susceptibility Testing of the Test Organism: Antimicrobial disc tests of the isolates 
were performed according to the recommendations of the National Committee Laboratory Standards (2000) using the following antibiotic discs:, ampiclox (30ug), zinnacef (20ug), amoxicillin (30ug), rocephin (25ug), ciprofloxacin (10ug), streptomycin (30ug), augmentin (20ug), sparfloxacin (30ug) erythromycin (10ug), gentamycin (10ug), septrin (30ug), chloramphenicol (25ug), perfloxacin (10ug), and ofloxacin (30ug) and antibiotics resistance was interpreted by diameter of inhibition zones around the antibiotic discs.

Antibacterial Susceptibility Testing of the Extracts with Test the Organisms: The inocula were prepared by inoculating the test organisms in nutrient broth and they were incubated for $24 \mathrm{hr}$ at $37^{\circ} \mathrm{C}$. The cultures were diluted to $0.5 \mathrm{McF}$ arland turbidity standard after the incubation. 0.2 milliliter of the cultures was further diluted in normal saline and were inoculated onto solidified nutrient agar using glass rod by spreading technique. The ability of the various extracts to inhibit the growth of the clinical test organisms was determined using the agar well technique.

The inoculated nutrients agar plates were allowed to dry. After which, wells were bored on the surface of inoculated agar plates using $4 \mathrm{~mm}$ cork borer. $0.2 \mathrm{ml}$ of the different concentration of each extracts were transferred into the well using Pasteur pipette. The wells were sufficiently spaced to prevent the resulting zones of inhibition from overlapping. The plates were incubated at $37^{\circ} \mathrm{C}$ for $24 \mathrm{hr}$. The experiment was performed in triplicate and the resulting zones of inhibition were recorded as mean \pm standard error

$\begin{array}{cccc}\text { Determination } & \text { of Minimum } & \text { Inhibitory } \\ \text { Concentration } & (M I C) & \text { and } & \text { Minimum }\end{array}$ Bactericidal Concentration (MBC): The minimum inhibitory concentration (MIC) of the methanol extracts was determined for each of the test organisms in triplicates at varying concentrations of $200,100,50,25,12.5,6.25$ and $3.125 \mathrm{mg} / \mathrm{ml}$ ). One milliliter $(1 \mathrm{ml})$ of nutrient broth was added and then a loopful of the test organism previously diluted to 0.5 McFarland turbidity standard was introduced to the tubes. A tube containing nutrient broth only was seeded with the test organism to serve as control. All the tubes were then incubated at $37^{\circ} \mathrm{C}$ for 24 hours and then examined for growth by observing for turbidity.

The minimum bactericidal concentration (MBC) of the plant extract on the clinical bacterial isolates was carried out according to Ajaiyeoba et al. (2003). Briefly, $1 \mathrm{ml}$ bacterial culture was pipetted from the mixture obtained in the determination of MIC tubes which did not show any growth and were sub-cultured onto nutrient agar and incubated at $37^{\circ} \mathrm{C}$ for 24 hours.
After incubation the concentration at which there was no single colony of bacteria was taken as MBC.

\section{RESULTS AND DISCUSSION}

Vernonia amygdalina serves as vegetables and is used the preparation of food nutritive seasoning used in the preparation of food. Apart from its nutritive value, it has been found to be potential in inhibiting the growth of microorganisms. Several research works have reviewed the nutritive, chemical and proximate analysis of $V$. amygdalina. Researchers have also studied the phytochemical and antimicrobial properties of leaf and stem extract.

Phytochemicals present in Vernonia amygdalina included flavonoids, cardiac glycosides, reducing sugar, terpenoids, saponins, anthraquinones, alkaloids and steroids as shown in table 1. These phytochemicals were present in both aqueous and ethanol extract. Tannin was observed to be absent in both aqueous and ethanolic extract of $V$ amygdalina. Akinjogunla et al. (2011) reported the presence of Carbohydrates, saponins, flavonoid and phlobatannin in $V$. amygdalina extracts.

Table 1: Phytochemical analysis of ethanol and aqueous extracts of Vernonia amygdalina

\begin{tabular}{lll}
\hline Phytochemicals & Solvents \\
\hline & Ethanol & Aqueous \\
\hline Flavonoids & + & + \\
Tannins & - & - \\
Cardiac glycosides & + & + \\
Reducing sugars & + & + \\
Terpenoids & + & + \\
Saponins & + & + \\
Anthraquinones & + & + \\
Alkaloids & + & + \\
Steroids & + & + \\
\hline \multicolumn{2}{c}{ Key: + = present; - = absent }
\end{tabular}

The antibacterial activity of $V$ amygdalina was found to be dependent on the nature of the solvent used for extraction and the concentration of the extract. Ethanolic extract was observed to possess more antibacterial activities compared to the aqueous extract. This is attributable to the fact that ethanol extracted more of the bioactive component of the plant compared to aqueous. Zones of inhibition produced by ethanolic extract ranged from $7.0 \pm 0.0 \mathrm{~mm}$ at $25 \mathrm{mg} / \mathrm{ml}$ to $14.5 \pm 2.5 \mathrm{~mm}$ at $200 \mathrm{mg} / \mathrm{ml}$ against $E$. coli; $6.5 \pm 0.5 \mathrm{~mm}$ at $100 \mathrm{mg} / \mathrm{ml}$ to $9.0 \pm 2.0 \mathrm{~mm}$ at $200 \mathrm{mg} / \mathrm{ml}$ against $S$. aureus; $11.0 \pm 1.0 \mathrm{~mm}$ at $50 \mathrm{mg} / \mathrm{ml}$ to $16.5 \pm 5.0 \mathrm{~mm}$ at $200 \mathrm{mg} / \mathrm{ml} ; 7.5 \pm 1.5 \mathrm{~mm}$ at $25 \mathrm{mg} / \mathrm{ml}$ to $11.5 \pm 0.5 \mathrm{~mm}$ at $200 \mathrm{mg} / \mathrm{ml}$ (Table 2). The most sensitive organisms to the ethanolic extract were $K$. pneumonia, E. coli and $P$. aeruginosa while $S$. aureus was the least sensitive. In all, ethanolic extract was found to possess inhibitory activities against the test bacterial species. This finding is in agreement with earlier work by Udochukwu et al. (2015) who reported 
the phytochemical and antibacterial activity of Vernonia amygdalina.

The aqueous extract was found not to inhibit some of the test organisms at lower concentrations. However, at higher concentration, zones of inhibition were observed. It ranged from $8.0 \pm 2.0 \mathrm{~mm}$ at $25 \mathrm{mg} / \mathrm{ml}$ to $12.5 \pm 1.5$ at $200 \mathrm{mg} / \mathrm{ml}$ against $P$. aeruginosa; $9.0 \pm 1.0 \mathrm{~mm}$ at $50 \mathrm{mg} / \mathrm{ml}$ to $15.0 \pm 1.5 \mathrm{~mm}$ at $200 \mathrm{mg} / \mathrm{ml}$ against $S$ aureus (Table 3 ).

Table 2: Antibacterial activity of Vernonia amygdalina ethanolic extract (zones of inhibition are measured in milimeters, mm.)

\begin{tabular}{|c|c|c|c|c|c|c|}
\hline $\begin{array}{l}\text { Test } \\
\text { organisms }\end{array}$ & & $\begin{array}{l}\text { Concentrations } \\
(\mathrm{mg} / \mathrm{ml})\end{array}$ & & & & \\
\hline & 200 & 100 & 50 & 25 & 12.5 & 6.25 \\
\hline E. coli & $14.5 \pm 2.5$ & $13.5 \pm 1.5$ & $11.0 \pm 2.8$ & $7.0 \pm 0.0$ & $0.0 \pm 0.0$ & $0.0 \pm 0.0$ \\
\hline S. aureus & $9.0 \pm 2.0$ & $6.5 \pm 0.5$ & $0.0 \pm 0.0$ & $0.0 \pm 0.0$ & $0.0 \pm 0.0$ & $0.0 \pm 0.0$ \\
\hline P. aeruginosa & $16.0 \pm 5.0$ & $11.5 \pm 0.5$ & $11.0 \pm 1.0$ & $0.0 \pm 0.0$ & $0.0 \pm 0.0$ & $0.0 \pm 0.0$ \\
\hline B. subtilis & $14.0 \pm 0.0$ & $10.5 \pm 0.5$ & $7.0 \pm 0.0$ & $0.0 \pm 0.0$ & $0.0 \pm 0.0$ & $0.0 \pm 0.0$ \\
\hline K. pneumonia & $11.5 \pm 0.5$ & $8.5 \pm 1.5$ & $8.0 \pm 0.0$ & $7.5 \pm 1.5$ & $0.0 \pm 0.0$ & $0.0 \pm 0.0$ \\
\hline
\end{tabular}

Escherichia coli was observed to be completely resistance to all concentrations of the plant extract. It is clear from this research that the test bacterial isolates were differentially affected by the ethanol and aqueous extract. This is due to variations in the dissolution capacity of the different solvents which in turn affected the degree of phytochemicals extracted. This resistance may have arisen from drug/phytochemical inactivating enzymes present in $E$. coli. Also, variations observed in the susceptibility of Gram positive and negative bacteria could have resulted from their relative composition of cell wall components. Gram positive bacteria have thick peptydoglycan layer, while Gram negative have thick lipopolysaccharide layer. These layers differential resist antibacterial agents.

Table 3: Antibacterial activity of aqueous Vernonia amygdalina extract (zones of inhibition are measured in milimeters, mm.)

\begin{tabular}{|c|c|c|c|c|c|c|}
\hline \multirow{2}{*}{$\begin{array}{l}\text { Test } \\
\text { organisms }\end{array}$} & \multicolumn{6}{|c|}{ Concentrations, $(\mathrm{mg} / \mathrm{ml})$} \\
\hline & 200 & 100 & 50 & 25 & 12.5 & 6.25 \\
\hline E. coli & $0.0 \pm 0.0$ & $0.0 \pm 0.0$ & $0.0 \pm 0.0$ & $0.0 \pm 0.0$ & $0.0 \pm 0.0$ & $0.0 \pm 0.0$ \\
\hline S. aureus & $15.5 \pm 1.5$ & $11.5 \pm 1.5$ & $9.0 \pm 1.0$ & $0.0 \pm 0.0$ & $0.0 \pm 0.0$ & $0.0 \pm 0.0$ \\
\hline P. aeruginosa & $12.5 \pm 1.5$ & $10.0 \pm 0.0$ & $9.0 \pm 2.0$ & $8.0 \pm 2.0$ & $0.0 \pm 0.0$ & $0.0 \pm 0.0$ \\
\hline B. subtilis & $12.0 \pm 0.0$ & $9.5 \pm 0.5$ & $7.0 \pm 0.0$ & $0.0 \pm 0.0$ & $0.0 \pm 0.0$ & $0.0 \pm 0.0$ \\
\hline K. pneumoniae & $11.5 \pm 0.5$ & $8.5 \pm 1.5$ & $0.0 \pm 0.0$ & $0.0 \pm 0.0$ & $0.0 \pm 0.0$ & $0.0 \pm 0.0$ \\
\hline
\end{tabular}

The minimum inhibitory concentration of ethanolic extract was found to range from $25 \mathrm{mg} / \mathrm{ml}$ in $E$. coli and $K$. Pneumoniae to $100 \mathrm{mg} / \mathrm{ml}$ in $S$. aureus. While that of aqueous extract ranged from $50 \mathrm{mg} / \mathrm{ml}$ in $S$. aureus to $100 \mathrm{mg} / \mathrm{ml}$ in $B$. subtilis. Minimum bactericidal concentration of the ethanol extract was $50 \mathrm{mg} / \mathrm{ml}$ in $\mathrm{K}$. pneumonia and $100 \mathrm{mg} / \mathrm{ml}$ for $E$. coli and $200 \mathrm{mg} / \mathrm{ml}$ in $S$. aureus. MBC of $200 \mathrm{mg} / \mathrm{ml}$ was observed for B. subtilis, S. aureus and P. aeruginosa in the aqueous fraction of the plant while no $\mathrm{MBC}$ was detected for other bacterial strain as summarized in Table 4. The potency of an antibacterial agent is an inverse measurement of its MIC and MBC. Plant extract or drugs that have low MIC and MBC against bacteria are said to be very potent. The reverse is also true for antimicrobial agents.

Table 4: MIC and MBC of ethanolic and aqueous extract of Vernonia amygdalina

\begin{tabular}{lllll}
\hline Test organisms & MIC $(\mathrm{mg} / \mathrm{ml})$ & MBC $(\mathrm{mg} / \mathrm{ml})$ & \\
\hline & Ethanol & Aqueous & Ethanol & Aqueous \\
\hline E. coli & 25 & - & 100 & - \\
S. aureus & 100 & 50 & 200 & 200 \\
P. aeruginosa & 50 & 50 & 100 & 200 \\
B. Subtilis & 50 & 100 & 100 & 200 \\
K. pneumonia & 25 & 100 & 50 & - \\
\hline
\end{tabular}

\begin{tabular}{|c|c|c|c|c|c|c|c|c|c|c|c|}
\hline & & & & \multicolumn{5}{|c|}{ Table 5: Antibiotic susceptibility test } & & & \\
\hline Gram +ve & CPX & St & SXT & $\mathbf{E}$ & PEF & $\mathbf{C N}$ & APX & $\mathbf{Z}$ & $\mathbf{A M}$ & Ro & Resistance (\%) \\
\hline S. aureus & $\mathrm{R}$ & $\mathrm{R}$ & $\mathrm{R}$ & $\mathrm{R}$ & $\mathrm{S}$ & $\mathrm{R}$ & $\mathrm{R}$ & $\mathrm{S}$ & $\mathrm{R}$ & $\mathrm{R}$ & 80 \\
\hline B. subtilis & $\mathrm{S}$ & $\mathrm{R}$ & $\mathrm{R}$ & $\mathrm{S}$ & $\mathrm{S}$ & $\mathrm{S}$ & $\mathrm{S}$ & $\mathrm{R}$ & $\mathrm{R}$ & $\mathrm{S}$ & 40 \\
\hline Gram -ve` & $\mathbf{C H}$ & SP & $\mathbf{A U}$ & OFX & SXT & PEF & $\mathbf{A M}$ & $\mathbf{S}$ & $\mathbf{C N}$ & CPX & \\
\hline E.coli & $\mathrm{S}$ & $\mathrm{S}$ & $\mathrm{R}$ & $\mathrm{R}$ & $\mathrm{S}$ & $\mathrm{S}$ & $S$ & $\mathrm{R}$ & $\mathrm{R}$ & $S$ & 40 \\
\hline P. aeruginosa & $\mathrm{S}$ & $\mathrm{S}$ & $\mathrm{S}$ & $\mathrm{S}$ & $\mathrm{S}$ & $\mathrm{S}$ & $\mathrm{S}$ & $\mathrm{R}$ & $\mathrm{S}$ & $\mathrm{S}$ & 10 \\
\hline K. pneumonia & $\mathrm{R}$ & $\mathrm{S}$ & $\mathrm{S}$ & $\mathrm{S}$ & $\mathrm{S}$ & $\mathrm{S}$ & $\mathrm{R}$ & $\mathrm{R}$ & $\mathrm{S}$ & $\mathrm{S}$ & 30 \\
\hline
\end{tabular}

KEY: CPX-Ciprofloxacin, Ro-Rocephin, St-Streptomycin, AU-Augmentin, SXT-Septrin, SP- Sparfloxacin, E-Erythromycin, CHChloramphenicol, PEF-Pefloxacin, CPX- ciprofloxacin,CN-Gentamicin,APX-Apmpiclox, AM-Amoxacillin, Z-Zinnacef 
The bacterial strains used for this study were screened for antibiotics sensitivity and were discovered to possess varying degree of antibiotics resistance as presented in tables 5. Ten different antibiotics were used and the organisms were selectively resistant to the antibiotics. The most resistant bacterium strain was $S$. aureus $(80 \%)$ while the least resistant was $P$. aeruginosa (10\%). The most effective antibiotics were perfloxacin, ciprofloxacin, septrin and choramphenicol. The organisms were resistance due to plasmid borne or chromosomally mediated resistant genes. Comparatively, the Vernonia amygdalina extract was more potent antibacterial substance than conventional antibiotics.

Conclusion: This research work has shown that Vernonia amygdalina has potential bioactive phytochemicals that are responsible for its antibacterial activities. It has also proven that bitter leaf extract is a more antibacterial substance than conventionally used antibiotics. Therefore, more research should be carried out to enable the purification of the specific biopotential chemicals and their subsequent processing into chemotherapeutic agents.

\section{REFERENCES}

Ajaiyeoba, EO; Onocha, PA; Nwozo, SO; Sama, W (2003). Antimicrobial and cytotoxicity evaluation of Buchholzia coriacea stem bark. Phytotherapy 74: 706-709.

Akinjogunla, OJ; Ekoi, OH; Odeyemi, AT; Akinjogunla, OJ; Etok, CA; Oshoma, CE (2011). Preliminary phytochemistry and in-vitro antibacterial efficacy of Hydro-Ethanolic leaf extracts of Psidium guajava on common urinary tract bacterial pathogens. Biores. Bull. 5: 329-336.

Akinjogunla, OJ; Adegoke, AA; Udokang, IP; Adebayo-Tayo, BC (2009). Antimicrobial potential of Nymphaea lotus (Nymphaeaceae) against wound pathogens. J. Med. Plants Res. 3(3):138-141.

Ibrahim, TA; Lola, A; Adetuyi, FO; Jude-Ojei, B (2009). Assessment of the antibacterial activity of Vernonia amygdalina and Ocimum gratissimum leaves on selected food borne pathogens. Inter. J. Third World Med. 8 (2): 23-24.

Idris, S; Ndukwe, GI; Gimba, CE (2009). Preliminary phytochemical screening and antimicrobial activity of seed extract of persea Americana (avocado pear). Bayero J. Pure Appl. Sci. 2(1): $173-176$
Izevbigie, EB; Bryant, JL; Walker, A (2004). A novel natural inhibitor of extracellular signal related kinases and human breast cancer cell growth. Experiment. Biol. Med. 229: 163-169.

Koshy, P; Sri-Nurestri, AM; Wira-Karnian, S; Sim, KS; Saravana, K; Hong, SL; Lee, GS; Syarifat, NSA (2009). Antimicrobial activity of some medicinal plants from Malasia. Amer. J. Appl. Sci. 6 (8): 1613-1617.

Martino, PD; Gagniere, H; Berry, H; Bret, L (2002). Antibiotic resistance and virulence properties of Pseudomonas aeruginosa strains from mechanically ventilated patient with pneumonia in intensive care unit: Comparison with imipenemresistant extra-respiratory tract isolates from uninfected patients. Microb. Infect. 4:613-620.

National Committee for Clinical Laboratory Standards NCCLS (2000). Methods for Dilution antimicrobial susceptibility tests for bacteria that grow aerobically: approved standards- fifth edition. NCCLS document M7-A5. NCCLS: Wayne, PA, USA.

Oboh, FOJ; Masodje, HI (2009). Nutritional and Antimicrobial Properties of Vernonia amygdalina Leaves. Inter. J. Biomed. Health Sci. 5(2): 51-56.

Pravi, CT (2006). Medicinal plants: traditional knowledge. International Pvt. Ltd. New Delhi. 216 p.

Preethi, RM; Devanathan, VV; Loganathan, M (2010). Antimicrobial and antioxidant efficacy of some medicinal plants against food borne pathogens. Adv. Biol. Res. 4: 122-125

Sofowora, EA (1993). Medicinal plants and Medicine in Africa (2nd eds). John Wiley and Sons, New York. 116pp.

Udochukwu, U; Omeje, FI; Uloma, ISF; Oseiwe, D (2015). Phytochemical analysis of Vernonia amygdalina and Ocimum gratissimum extracts and their antibacterial activity on some drug resistant bacteria. Amer. J. Res. Communication 3(5): 225-235

Yedjou, C; Izevbigie, E; Tchounwou, P (2008). Preclinical assessment of Vernonia amygdalina leaf extracts as DNA damaging anti-cancer agent in the management of breast Cancer. Inter. J. Environ. Res. Public Health 12:123-127. 